\title{
In vitro anti-proliferative effect and in vivo antitumor action of daphnetin in different tumor cells
}

\author{
Efectos antiproliferativos in vitro y acciones antitumorales in vivo de la dafnetina en \\ diferentes células tumorales
}

\author{
F. Alejandro Jiménez-Orozco ${ }^{1 *}$, Ivan Ranđelović2, Zita Hegedüs², Armando Vega-Lopez ${ }^{3}$, \\ Francisco Martínez-Flores ${ }^{4}$, and József Tóvari' \\ ${ }^{1}$ Department of Pharmacology, School of Medicine, Universidad Nacional Autónoma de Mexico, Mexico City, Mexico; ${ }^{2}$ Department of Experimental \\ Pharmacology, National Institute of Oncology, Budapest, Hungary; ${ }^{3}$ Environmental Toxicology Laboratory, Escuela Nacional de Ciencias Biológicas, \\ Instituto Politécnico Nacional, Mexico City, Mexico; ${ }^{4}$ Skin and Tissue Bank, Instituto Nacional de Rehabilitación, Secretaría de Salud, Mexico City, \\ Mexico
}

\begin{abstract}
Background: The anti-inflammatory effects of daphnetin (7,8-dihidroxicoumarin) have been well-documented, but the potential of daphnetin as an anticancer agent is controversial and remains insufficiently explored. Material and methods: In this work, we evaluated the in vitro anti-proliferative effect of daphnetin in three cell lines by 3-(4,5-dimethylthiazol-2-yl)-2,5-diphenyltetrazolium bromide assays, as well as its in vivo antitumor effect in four different types of mouse tumor. Results: With a correlation between in vitro and in vivo results, the tested cell types have different sensitivity to the compound. The following cell lines are arranged according to the in vitro anti-proliferative potency of daphnetin: B16 melanoma cells (inhibitory concentrations $\left.50\left[I C_{50}\right]=54 \pm 2.8 \mu \mathrm{M}\right)>$ mitoxantrone $(\mathrm{MXT})$ breast adenocarcinoma cells $\left(\mathrm{IC}_{50}=74 \pm 6.4 \mu \mathrm{M}\right)>$ C26 colon carcinoma cells $\left(I C_{50}=108 \pm 7.3 \mu \mathrm{M}\right)$. In vivo, the optimal antitumor dose of daphnetin was $40 \mathrm{mg} / \mathrm{kg}$ and the magnitudes of inhibition were the following: B16 tumor (48\%) > MXT tumor (40\%) > S180 fibrosarcoma tumor (30\%) > C26 tumor (20\%). Conclusion: Our results indicate that daphnetin might have an impact as adjuvant to improve the effectiveness of conventional chemotherapy.
\end{abstract}

Key words: Daphnetin. Coumarins. Antiproliferation. Antitumor activity. Tumor chemotherapy.

\section{Resumen}

Antecedentes: Los efectos antiinflamatorios de la dafnetina (7,8-dihidroxicumarina) han sido bien documentados, pero su potencial como agente anticanceroso es controversial y no se ha explorado suficientemente. Material y métodos: En este trabajo se evalúa el efecto antiproliferativo in vitro de la dafnetina en tres líneas celulares mediante ensayos de MTT, así como su efecto antitumoral in vivo en cuatro diferentes tipos de tumores en ratones. Resultados: Con una correlación entre los resultados in vitro e in vivo, los tipos de células probadas tienen diferente sensibilidad al compuesto. Las siguientes líneas celulares están ordenadas de acuerdo con la potencia antiproliferativa in vitro de la dafnetina: células de melanoma B16 $\left(I_{50}=54\right.$ $\pm 2.8 \mu \mathrm{M})>$ células de adenocarcinoma de mama MXT $\left(I C_{50}=74 \pm 6.4 \mu \mathrm{M}\right)>$ células de carcinoma de colon C26 $\left(I C_{50}=108\right.$

\footnotetext{
Correspondence:

${ }^{*}$ F. Alejandro Jiménez-Orozco

Ciudad Universitaria, 3000

Col. Copilco-Universidad, Del.Coyoacán

C.P. 04360 , Mexico City, Mexico

Date of reception: 27-02-2018

Cir Cir. 2020;88(6):765-771

E-mail: alejandrojimenezorozco@gmail.com

Date of acceptance: 05-04-2020

DOI: 10.24875/CIRU.20000197

Contents available at PubMed

www.cirugiaycirujanos.com

0009-7411/@ 2020 Academia Mexicana de Cirugía. Published by Permanyer. This is an open access article under the terms of the CC BY-NC-ND license (http://creativecommons.org/licenses/by-nc-nd/4.0/).
} 
$\pm 7.3 \mu \mathrm{M})$. In vivo, la dosis antitumoral óptima de dafnetina fue de $40 \mathrm{mg} / \mathrm{kg}$, y las magnitudes de inhibición fueron las siguientes: tumor B16 (48\%) > tumor MXT (40\%) > tumor fibrosarcoma S180 (30\%) > tumor C26 (20\%). Conclusión: Los resultados indican que la dafnetina podría tener un impacto como adyuvante para mejorar la efectividad de la quimioterapia convencional.

Palabras clave: Dafnetina. Cumarinas. Antiproliferación. Actividad antitumoral. Quimioterapia tumoral.

\section{Introduction}

Phytochemicals are natural molecules found in many foods and medicinal plants, which play an important role in the prevention and treatment of chronic diseases. Because of their anti-inflammatory, antioxidant and anticancer effects, phytochemicals are becoming increasingly accepted in Western countries'. Some of the most studied phytochemicals are genistein, resveratrol, epigallocatechin gallate, and curcumin ${ }^{2}$. It has been proposed that the implementation of these phytochemicals as adjuvants in the treatment of cancer could improve the efficacy of chemotherapy ${ }^{3}$. Therefore, their potential effectiveness against different cancers is being evaluated in clinical trials (http://www.clinicaltrials.gov/). Furthermore, there are other natural molecules that are already used in humans for the treatment of other chronic diseases and whose actions could also improve the treatments by conventional chemotherapy.

Daphnetin (7,8-dihydroxycoumarin) is a secondary metabolite of plants used in Traditional Chinese Medicine for pain and rheumatoid arthritis ${ }^{4,5}$. Its anti-inflammatory actions occur mainly through the modulation of the immune system by downregulating the activation of NF-kB and other signaling pathways, which suppress the production of many pro-inflammatory cytokines $^{6-9}$. In addition, daphnetin also has antioxidant $^{10}$, antimicrobial ${ }^{11}$, antimalarial ${ }^{12}$ and antiangiogenic properties ${ }^{13}$.

Among simple coumarins, this compound has the greatest kinases inhibitory activity ${ }^{14}$, which inhibits several mitogenic pathways and induces an important anti-proliferative effect in some tumor cell lines ${ }^{15}$. Its kinase inhibitory activity is consistent with the reduction of cyclin D1 and the cell cycle inhibition in Sphase in Michigan Cancer Foundation (MCF)-7 human breast carcinoma cells ${ }^{16}$.

Daphnetin induces apoptosis in a concentrationdependent manner by inhibiting the anti-apoptotic Akt/ NF-кB pathways, which produces upregulation of the pro-apoptotic caspase-3 in A549 human lung adenocarcinoma cells ${ }^{17}$.

Daphnetin also activates p38 mitogen-activated protein kinase in concentration- and time-dependent manner in the A498 human kidney adenocarcinoma cell line. That correlates with the expression of cellular differentiation markers CK18 and CK8. In addition to its greater cytostatic activity, the following factors contribute to making daphnetin a promising compound to be evaluated as an anticancer agent: (a) it is not mutagenic; (b) it does not intercalate DNA, but rather inhibits its synthesis; (c) it is not a substrate for glycoprotein $\mathrm{P}$, and therefore its anti-proliferative effect will not be affected by the phenotype of multiple drug resistance ${ }^{18}$.

In contrast, Kimura et al. ${ }^{19}$ did not observe the antiproliferative or antitumor effect of daphnetin in osteosarcoma LM8 cells (in vitro) and a highly metastatic model in LM8-bearing mice (in vivo).

To clarify the anticancer effectiveness of daphnetin, the aim of the present work was to evaluate more extensively the in vitro anti-proliferative effect of daphnetin in tumor cell lines not yet studied at this respect, and in addition, to evaluate its in vivo antitumor effect in four different types of murine tumors.

Here, we present that based on the calculated inhibitory concentrations $50\left(\mathrm{IC}_{50}\right) \mathrm{s}$, daphnetin was most effective in B16 murine melanoma cells followed by mitoxantrone (MXT) murine breast adenocarcinoma cells and C26 murine colon carcinoma cells. Regarding the in vitro potency of daphnetin, a correlation was observed with the in vivo experiments. The B16 tumors were the most sensitive to daphnetin followed by MXT tumors, S-180 murine fibrosarcoma tumors, and C26 tumors.

\section{Materials and methods}

\section{Compounds}

Daphnetin (7,8-dihydroxycoumarin), dimethyl sulfoxide (DMSO), absolute ethanol, and (3-(4,5-dimethylthiazol-2-yl)-2,5-diphenyl tetrazolium bromide [MTT]) were commercially supplied by Sigma-Aldrich (St. Louis, MO, USA).

\section{Cell lines and tumors}

B16 murine melanoma cell line, MXT murine breast adenocarcinoma cell line, and C26 murine colon 
carcinoma cell lines were purchased from the American Type Culture Collection (Manassas, VA, USA). MXT cells were routinely cultivated at $37^{\circ} \mathrm{C}$ in humidity, with $5 \% \mathrm{CO}_{2}$ in Roswell Park Memorial Institute-1640 medium, supplemented with $10 \%(\mathrm{v} / \mathrm{v})$ fetal bovine serum, $1 \%(\mathrm{v} / \mathrm{v})$ pyruvate, and a $1 \%(\mathrm{v} / \mathrm{v})$ antibiotic-antimycotic mix (penicillin G sodium, streptomycin sulfate and amphotericin B). B16 melanoma cells and C26 cells were cultivated in Dulbecco's Modified Eagle's Medium supplemented as above. S180 sarcoma was obtained from the Chester Beatty Cancer Research Institute, London, UK.

\section{Cytostatic MTT assay}

The cytostatic effect of compound tested on the tumor cells was estimated using the microculture MTT assay. The assay is based on the reduction of soluble tetrazolium salt by mitochondria of viable cells. The reduced product, an insoluble purple-colored formazan, was dissolved in DMSO and measured spectrophotometrically $(570 \mathrm{~nm})$. Under the experimental conditions of this study, the amount of formazan was proportional to the number of viable cells. Cells $(2 \times$ $\left.10^{3}\right)$ were seeded in each well of a 96 well microplate in a $200 \mu \mathrm{L}$ of medium and after overnight incubation, the medium was replaced with fresh media containing the corresponding concentration of daphnetin $(10,20$, $40,80,160$, and $320 \mu \mathrm{M})$. Ethanol was used as a solvent, and its maximal concentration in the medium was $0.5 \% \mathrm{v} / \mathrm{v}$. After $72-\mathrm{h}$ exposure, the percentage of proliferative inhibition of treated cells was estimated against the solvent-treated control cells $(\mathrm{P} \%=[\mathrm{T} / \mathrm{C}] \times$ 100). $\mathrm{P} \%=$ proliferation percentage; $T=$ absorbance of treated cells, $\mathrm{C}=$ absorbance of control cells. $\mathrm{IC}_{50}$ was calculated from the least square concentrationresponse regressions.

\section{Animals}

Female inbred BDF1 (for MXT and S180 tumors), C57BL/6 (for B16 tumor), and BALB/C (for C26 tumors) mice (8 weeks old) from a specified pathogen free breeding of the Department of Experimental Pharmacology, National Institute of Oncology (Budapest, Hungary) weighing 22-24 g were used for these experiments. The animals were fed with a sterilized standard diet (Biofarm, Budapest) and had access to tap water ad libitum. They were kept in Makrolon cages at $23-25^{\circ} \mathrm{C}(40-50 \%$ humidity), with a lighting regimen of $12 \mathrm{~h} / 12 \mathrm{~h}$ light/dark. The animals used in these studies were cared for according to the "Guiding Principles for the Care and Use of Animals" based on the Helsinki Declaration and which were approved by the local ethical committee (license number: PE/001/2574-6/2015). In our experiments, we utilized seven mice per group.

\section{Transplantation of the tumors}

An optimal fragment $(2 \times 2 \times 3 \mathrm{~mm})$ of $\mathrm{S} 180$ sarcoma, MXT breast adenocarcinoma, or C26 colon carcinoma tumor/mouse were transplanted subcutaneously (s. c.) into the intrascapular region of the mice ${ }^{20}$. The animals were anesthetized by i.p. injection of $20 \mathrm{mg} / \mathrm{kg}$ ketamine (Rationpharm, Ulm, Germany) and $12.5 \mathrm{mg} / \mathrm{kg}$ xylazine (Rompun, Bayer HealthCare, Leverkusen, Germany). B16 melanoma cells $\left(6 \times 10^{5} /\right.$ mouse) were inoculated into the intrascapular region of the mice. Treatment with daphnetin started after development of the tumor (on $7^{\text {th }}$ day). The animals were distributed among groups according to a balanced design based on initial tumor volume ( $n=7$ animals per group in each experiment), and groups were assigned randomly to treatments.

\section{In vivo treatment conditions, doses, and evaluation.}

Every day, before administration, fresh dilutions were prepared diluting daphnetin in DMSO and then in distilled water at $37^{\circ} \mathrm{C}$ (the final concentration of DMSO was $4 \% \mathrm{v} / \mathrm{v})$. On the basis of our previous experiments, daphnetin was administrated i.p. at doses of 10,20 and $40 \mathrm{mg} / \mathrm{kg}$ and the mice were treated for 14 days. Ratio of the volume/body weight was 0.1 $\mathrm{ml} / 10 \mathrm{~g}$. In all cases, mice of the control group have received water with DMSO at $4 \%(\mathrm{v} / \mathrm{v})$. The animals were weighed and the tumor volumes were measured with a micro caliper on every $2^{\text {nd }}$ or $3^{\text {rd }}$ days. The tumor volume was calculated with the following formula: $\mathrm{V}=(\pi / 6) \times \mathrm{L} / \mathrm{D}^{2}$ (V: tumor volume, L: longest diameter, $\mathrm{D}$ : diameter perpendicular to $\mathrm{L}$ ). Tumor volume measurements were continued until day 23 for tumors B16 and until day 18 for the other tumors. The results were expressed in means \pm standard error mean (SEM).

\section{Statistical analysis}

Statistical significance among groups was analyzed employing one-way analysis of variance (ANOVA). 

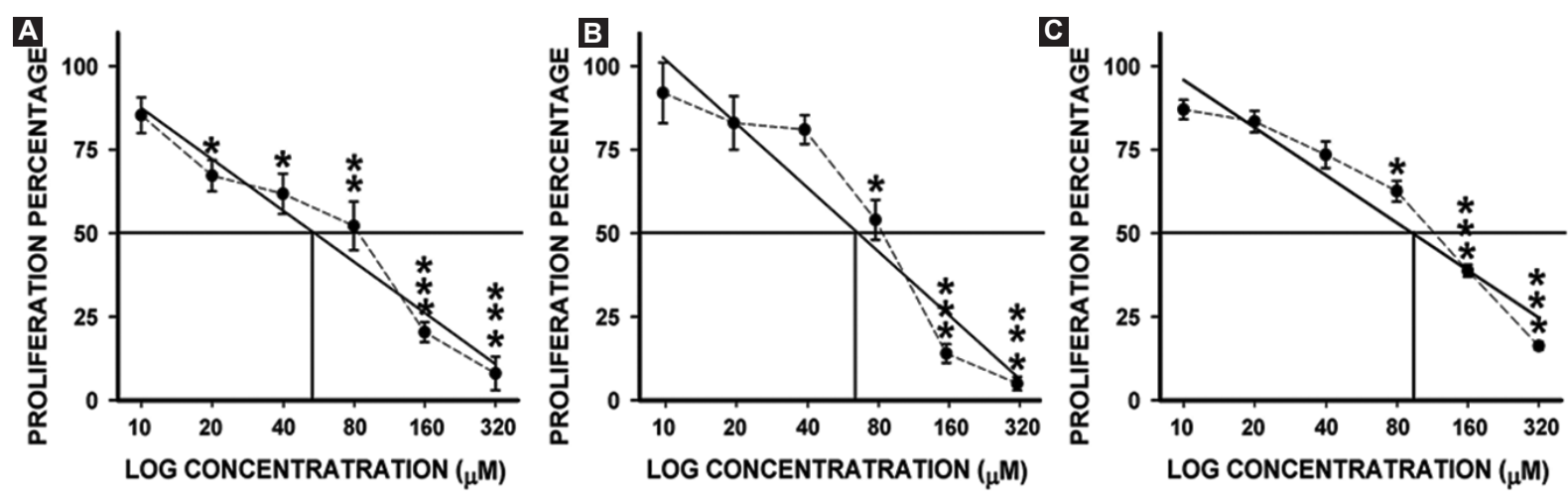

Figure 1. Anti-proliferative effect of daphnetin (10-320 $\mu \mathrm{M})$ at 3 days exposure in three murine tumor cell lines: (A) B16 melanoma cells $\left(I C_{50}=54\right.$ \pm 2.8 ), (B) mitoxantrone breast adenocarcinoma cells $\left(I C_{50}=74 \pm 6.4 \mu \mathrm{M}\right)$, and (C) C26 colon carcinoma cells $\left(I C_{50}=108 \pm 7.3 \mu \mathrm{M}\right)$. In all cases, at concentration of $80 \mu \mathrm{M}$ daphnetin inhibited significantly the proliferation near of $50 \%$ or less: ${ }^{*} p<0.05,{ }^{* *} p<0.01,{ }^{* * *} p<0.001$.

The significance of the differences among data of the control and treated groups of the in vitro cell proliferation assays and the in vivo antitumor assays were estimated by Dunn's or Dunnett's method, as required. The analysis was performed using the SigmaStat 3.1 program, Systat. The results were expressed in means \pm SEM. Values of $p<0.05$ were considered statistically significant. The in vitro data are representative of at least four independent experiments.

\section{Results}

\section{In vitro anti-proliferative effect of daphnetin}

In accordance with our previous works, at concentrations lower than $160 \mu \mathrm{M}$, although some small inhibitory effects were observed in all cell lines after 24- or 48-h exposure, the anti-proliferative effect became significant and concentration-dependent only after $72 \mathrm{~h}$ of exposure.

In all cases, at $320 \mu \mathrm{M}$ concentration, daphnetin produced cytotoxicity which was confirmed by Trypan blue exclusion (data not shown), but in the case of B16 and MXT cells the cytotoxicity become evident even at $160 \mu \mathrm{M}$.

All cell lines were inhibited by daphnetin at similar ranges of concentration, as the $\mathrm{IC}_{50}$ were in the range between 54 and $108 \mu \mathrm{M}$. However, some cell lines were more sensitive than others (Fig. 1). B16 cells were the most sensitive to daphnetin $\left(\mathrm{IC}_{50}=54 \pm\right.$ $2.8 \mu \mathrm{M})$ and the differences observed between the treated cells and control cells were statistically significant from the concentration of $20 \mu \mathrm{M}$. In contrast, in MXT cells $\left(\mathrm{IC}_{50}=74 \pm 6.4 \mu \mathrm{M}\right)$ and in C26 cells
$\left(\mathrm{IC}_{50}=108 \pm 7.3 \mu \mathrm{M}\right)$ were less sensitive to compound, because their anti-proliferative effect began to be statistically significant only at concentration of $80 \mu \mathrm{M}$.

\section{In vivo antitumor effect of daphnetin}

The antitumor activity of daphnetin in four different tumor types over time is shown in figure 2 . The percentage of tumor growth produced by daphnetin at different doses compared to the control group in the last evaluation day is shown in table 1.

\section{B16 MELANOMA TUMOR}

A statistically significant reduction of the tumor volume (approximately 35\%) was observed at day 16 and the magnitude of the antitumor effect was increased as time progressed. In the last evaluation day, the dose of $40 \mathrm{mg} / \mathrm{kg}$ produced the best response with $48 \%$ of inhibition $(p<0.05)$.

\section{MXT BREAST ADENOCARCINOMA TUMOR}

A significant tumor inhibition of approximately $35 \%$ was observed at day 11; however, the magnitudes of the effects were similar at different days. The best response was observed at dose of $40 \mathrm{mg} / \mathrm{kg}$ with $40 \%$ of inhibition $(p<0.05)$.

\section{S180 SARCOMA TUMOR}

The antitumor effect was observed from day 14 and a clear relation dose-dependent response was observed 
A

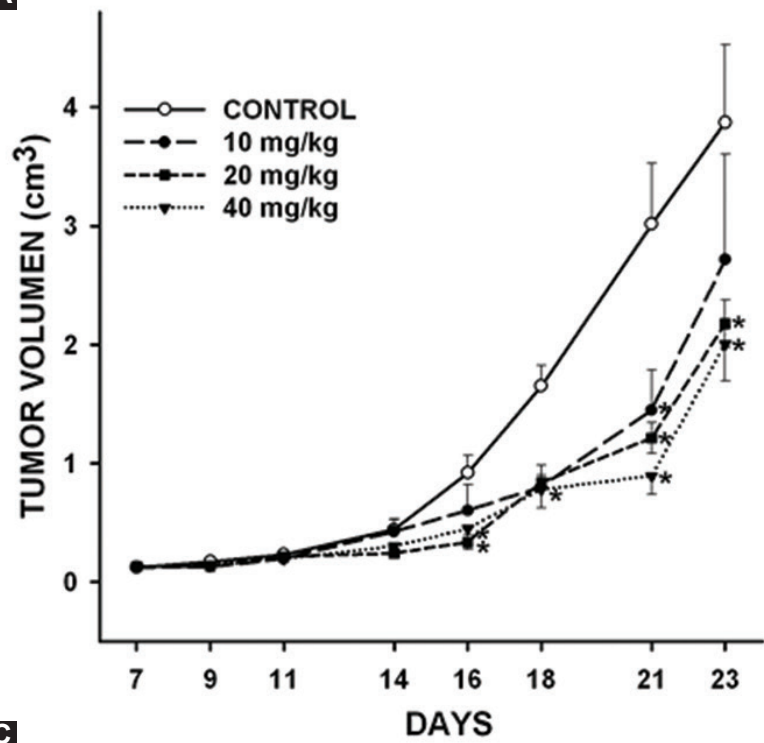

C

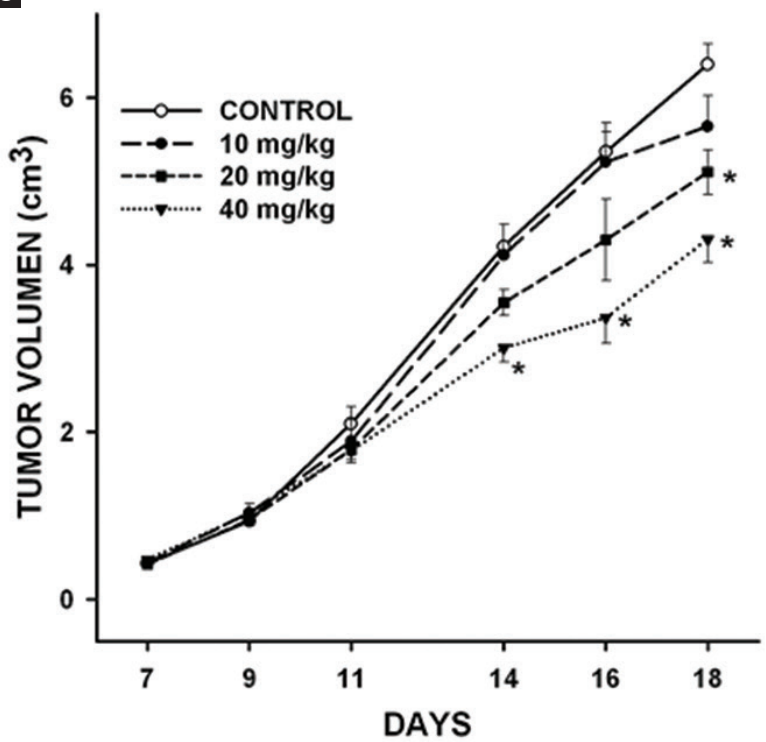

B
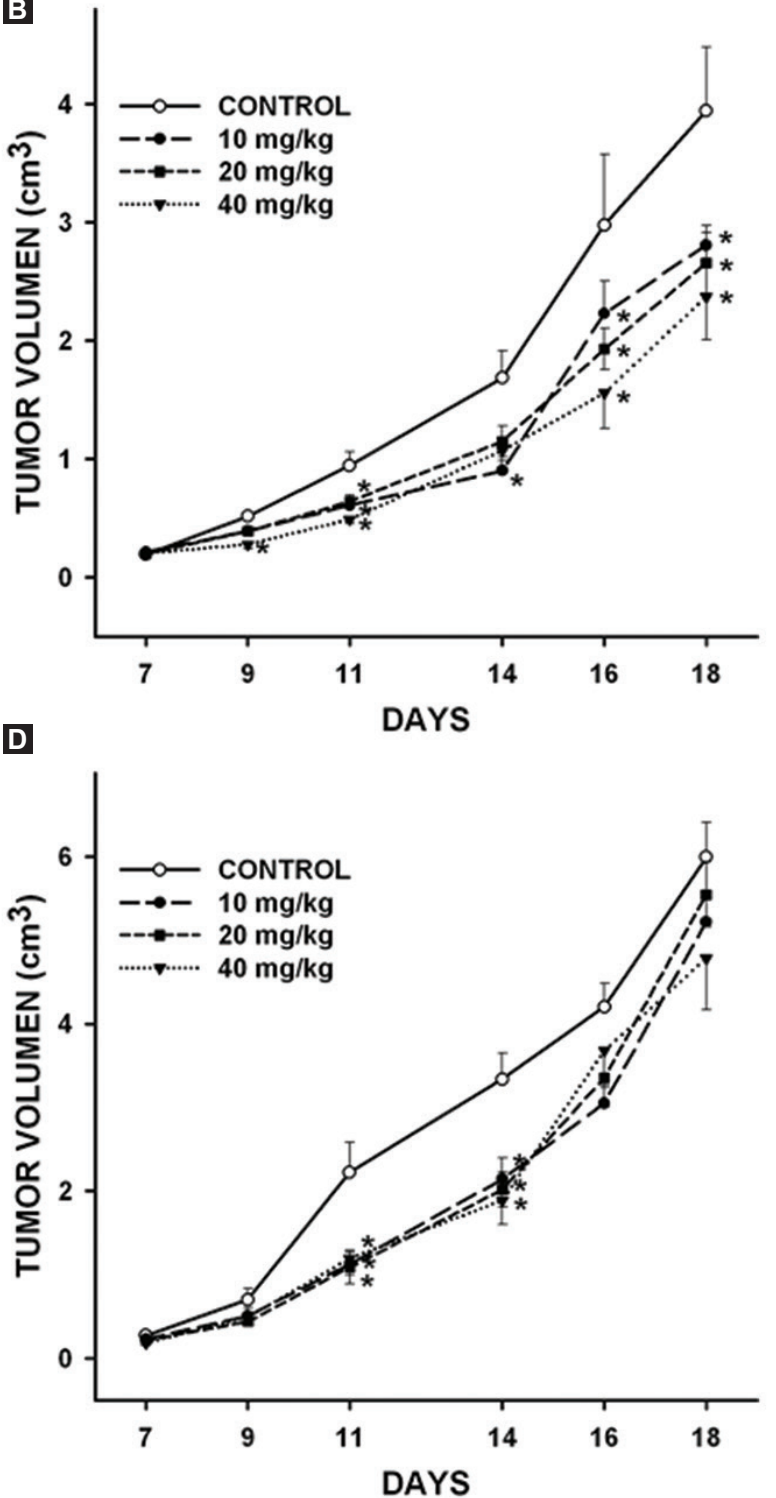

Figure 2. (A-D) Tumor growth inhibition by daphnetin (10 mg/kg, $20 \mathrm{mg} / \mathrm{kg}$, and $40 \mathrm{mg} / \mathrm{kg}$ ) in four different murine tumor models: B16 melanoma, mitoxantrone breast adenocarcinoma, S180 sarcoma, and C-26 colon carcinoma. ${ }^{*} p<0.05$.

each day. The best response of daphnetin was observed at dose of $40 \mathrm{mg} / \mathrm{kg}$ with $33 \%$ inhibition $(\mathrm{p}<0.05)$.

\section{C26 COLON CARCINOMA}

At day 11, all concentrations produced a meaningful antitumor effect $(p<0.05)$ of approximately $50 \%$ of inhibition in respect to the control group. On the last measurement day, the differences between treated and control were approximately $15 \%$. The best effect was observed at dose of $40 \mathrm{mg} / \mathrm{kg}$ with $20 \%$ of inhibition $(p<0.05)$.

\section{Discussion}

Among simple coumarins, esculetin (6,7-dihydroxycoumarin) is one of the most studied and it has been proposed as a potential anticancer agent ${ }^{21}$. Recently, Kimura et al. ${ }^{19}$ reported that esculetin inhibited the proliferation of osteosarcoma cells LM8 at 12 and $24 \mathrm{~h}$ of exposure, whereas any effect of daphnetin was not observed. However, it has been widely reported that the anti-proliferative effect of coumarin derivatives is dependent on both time and concentration and they are considerably more active in leukemia cell lines than in the cell lines derived from epithelial tumors ${ }^{22}$. 
Tabla 1. Antitumor effect of daphnetin in four different murine tumor model: B16 melanoma, S180 sarcoma, MXT breast adenocarcinoma and C-26 colon carcinoma on the last evaluation day

\begin{tabular}{|c|c|c|c|c|c|c|c|}
\hline Tumor type & $\begin{array}{c}\text { Dose } \\
(\mathrm{mg} / \mathrm{kg})\end{array}$ & $\begin{array}{c}\text { Dose } \\
(\mu \mathrm{mol} / \mathrm{kg})\end{array}$ & $\begin{array}{l}\text { Treatment } \\
\text { schedule }\end{array}$ & $\begin{array}{l}\text { Tumor volume } \\
\left(\mathrm{cm}^{3} \pm \text { SEM) }\right.\end{array}$ & $\begin{array}{c}\text { T/Cx100 } \\
\text { (\%) }\end{array}$ & $\begin{array}{l}\text { TGI } \\
(\%)\end{array}$ & Evaluation day \\
\hline B16 melanom & $\begin{array}{c}10 \\
20 \\
40 \\
\text { control }\end{array}$ & $\begin{array}{c}56 \\
112 \\
224\end{array}$ & $\begin{array}{l}14 \times \text { qd } \\
14 \times \text { qd } \\
14 \times \text { qd } \\
14 \times \text { qd }\end{array}$ & $\begin{array}{l}2.7 \pm 0.47^{*} \\
2.2 \pm 0.20^{*} \\
2.0 \pm 0.31^{*} \\
3.9 \pm 0.51\end{array}$ & $\begin{array}{l}70 \\
56 \\
52\end{array}$ & $\begin{array}{l}30 \\
44 \\
48\end{array}$ & $\begin{array}{l}23 \\
23 \\
23 \\
23\end{array}$ \\
\hline $\begin{array}{l}\text { MXT breast } \\
\text { adenocarcinoma }\end{array}$ & $\begin{array}{c}10 \\
20 \\
40 \\
\text { control }\end{array}$ & $\begin{array}{c}56 \\
112 \\
224\end{array}$ & $\begin{array}{l}14 \times \text { qd } \\
14 \times \text { qd } \\
14 \times \text { qd } \\
14 \times \text { qd }\end{array}$ & $\begin{array}{c}2.8 \pm 0.12^{*} \\
2.7 \pm 0.26^{*} \\
2.4 \pm 0.37^{*} \\
3.9 \pm 0.54\end{array}$ & $\begin{array}{l}71 \\
67 \\
60\end{array}$ & $\begin{array}{l}29 \\
33 \\
40\end{array}$ & $\begin{array}{l}18 \\
18 \\
18 \\
18\end{array}$ \\
\hline S180 Sarcoma & $\begin{array}{c}10 \\
20 \\
40 \\
\text { control }\end{array}$ & $\begin{array}{c}56 \\
112 \\
224\end{array}$ & $\begin{array}{l}14 \times \text { qd } \\
14 \times \text { qd } \\
14 \times \text { qd } \\
14 \times \text { qd }\end{array}$ & $\begin{array}{c}5.7 \pm 0.37 \\
5.1 \pm 0.27 \\
4.3 \pm 0.28^{*} \\
6.4 \pm 0.65\end{array}$ & $\begin{array}{l}88 \\
80 \\
67\end{array}$ & $\begin{array}{l}12 \\
20 \\
33\end{array}$ & $\begin{array}{l}18 \\
18 \\
18 \\
18\end{array}$ \\
\hline $\begin{array}{l}\text { C-26 colon } \\
\text { carcinoma }\end{array}$ & $\begin{array}{c}10 \\
20 \\
40 \\
\text { control }\end{array}$ & $\begin{array}{c}56 \\
112 \\
224\end{array}$ & $\begin{array}{l}14 \times \text { qd } \\
14 \times \text { qd } \\
14 \times \text { qd } \\
14 \times \text { qd }\end{array}$ & $\begin{array}{l}5.2 \pm 0.33 \\
5.5 \pm 0.39 \\
4.8 \pm 0.62 \\
6.0 \pm 0.42\end{array}$ & $\begin{array}{l}87 \\
93 \\
80\end{array}$ & $\begin{array}{c}13 \\
7 \\
20\end{array}$ & $\begin{array}{l}18 \\
18 \\
18 \\
18\end{array}$ \\
\hline
\end{tabular}

a:The day in which the first death was observed in the control group. TGI $=$ Tumor growth inhibition. $q d=$ each day. ${ }^{*}=p<0.05$

It is not clear why Kimura et al. did not observe the anti-proliferative effect of daphnetin. In contrast with their results, in our previous work, we have reported that the effect of coumarins became evident only after exposure for $72 \mathrm{~h}$ and daphnetin has a greater antiproliferative effect than esculetin in MCF-7 cell line ${ }^{16}$. The results of the present paper agree with our previous findings as well as with the other authors' in other cell lines ${ }^{17,18}$. According to the estimated $I C_{50} \mathrm{~S}$, daphnetin was more active in B16 cells, followed by MXT cells and C26 cells.

Our in vivo results demonstrated the antitumor effect of daphnetin in four different types of mouse tumors. Although the antitumor effect of daphnetin has different latency and magnitude in each mouse model, the best response was observed at the concentration of $40 \mathrm{mg} / \mathrm{kg}$ of the compound in all cases. Based on the magnitude of the effect on the last evaluation day, the sensitivity of the tumors to daphnetin was the following: B16 melanoma > MXT breast adenocarcinoma $>$ S180 sarcoma > C26 colon carcinoma.

Kimura et al..$^{19}$ did not observe the antitumor effect of daphnetin in osteosarcoma LM8-bearing mice at the concentration of $3 \mathrm{mg} / \mathrm{kg}$ and $10 \mathrm{mg} / \mathrm{kg}$. One part of our results is in agreement with this report, because at a $10 \mathrm{mg} / \mathrm{kg}$ dose, we have also observed no effect in S180 sarcoma. However, in the B16 melanoma and
MXT breast adenocarcinoma a significant antitumor effect were observed, this effect became more evident at higher concentrations. In addition, in the case of hormone dependent cancers such as breast cancer, daphnetin could potentially be safer because it does not have the estrogenic effect observed in esculetin ${ }^{16}$.

In accordance with the method of body surface area for dose translation from animal to human ${ }^{23}$, the dose of $40 \mathrm{mg} / \mathrm{kg}$ of daphnetin in mice corresponds to a human equivalent dose of $3.24 \mathrm{mg} / \mathrm{kg}$, which equates to a $227 \mathrm{mg}$ dose of daphnetin for a $70 \mathrm{~kg}$ person. The oral tablet commercially available for human consumption contains $300 \mathrm{mg}$ of daphnetin and the usual clinical dose range for daphnetin was $450 \mathrm{mg} 3$ times a day ${ }^{6}$.

Our results suggest that daphnetin could be beneficial to improving the efficacy of chemotherapy, as has been observed with other phytochemicals (http://www. clinicaltrials.gov/).

Daphnetin (7,8-dihydroxycoumarin) is a natural coumarin that has been developed successfully as an oral medicine for the clinical treatment of traumatic injury and rheumatoid arthritis in China since the 1980s. Unlike traditional anti-inflammatory agents (NSAIDs and glucocorticoids), its chronic use does not produce significant adverse effects, making it safer in humans. 
In the present work, the in vivo antitumor activity of daphnetin was demonstrated in four different types of mouse tumor and its in vitro anti-proliferative effect was corroborated in three tumor cell lines. Regarding the in vitro potency of daphnetin, a correlation was observed with the in vivo experiments. However, the possible changes in the expression of genes involved in antitumoral effect of daphnetin must be evaluated in future studies. The pleiotropic actions and low toxicity of this molecule represent a great advantage for its possible inclusion as adjuvant agent in human protocols to improve the efficacy of chemotherapy.

\section{Acknowledgments}

The corresponding author (F.A. Jiménez-Orozco) is grateful to Professor Edith Olah for allowing him to do research in her lab and providing him with training and tools at the Department of Molecular Genetics in the National Institute of Oncology, Budapest, Hungary. We would like to thank María Juana Gracía Mondragón for her support in carrying out the statistical analysis of the results, as well as the colleagues of the Departments of the Molecular Genetics and the Experimental Pharmacology of the National Institute of Oncology, for critical reading of the manuscript (Dr János Papp, Dr. Tibor Vaszkó) and for the excellent technical assistance.

\section{Conflicts of interest}

The authors declare have there no conflicts of interest.

\section{Funding}

This work was supported by grants OTKA K116295, TEMPUS PUBLIC FUNDATION 133561, PAPITTUNAM IN220517 and PASPA-DEGAPA, UNAM.

\section{Ethical disclosures}

Protection of human and animal subjects. The authors declare that the procedures followed were in accordance with the regulations of the relevant clinical research ethics committee and with those of the Code of Ethics of the World Medical Association (Declaration of Helsinki).

Confidentiality of data. The authors declare that they have followed the protocols of their work center on the publication of patient data.
Right to privacy and informed consent. The authors declare that no patient data appear in this article.

\section{References}

1. Gupta SC, Kim JH, Prasad S, Aggarwal BB. Regulation of survival, proliferation, invasion, angiogenesis, and metastasis of tumor cells through modulation of inflammatory pathways by nutraceuticals. Cancer Metastasis Rev. 2010;29:405-34.

2. Phuah NO, Nagoor NH. Regulation of microRNAs by natural agents: new strategies in cancer therapies. Biomed Res Int. 2014;2014:804510.

3. Russo M, Spagnuolo C, Tedesco I, Russo GL. Phytochemicals in cancer prevention and therapy: truth or dare? Toxins. 2010;2:517-51.

4. Gao Q, Shan J, Di L, Jiang L, Xu H. Therapeutic effects of daphnetin on adjuvant-induced arthritic rats. J Ethnopharmacol. 2008;120:259-63.

5. Tu L, Li S, Fu Y, Yao R, Zhang Z, Yang S, et al. The therapeutic effects of daphnetin in collagen-induced arthritis involve its regulation of Th17 cells. Int Immunopharmacol. 2012;13:417-23.

6. Song B, Wang Z, Liu Y, Xu S, Huang G, Xiong Y, et al. Immunosuppressive activity of daphnetin, one of coumarin derivatives, is mediated through suppression of NF- $\mathrm{KB}$ and NFAT signaling pathways in mouse T cells. PLoS One. 2014;9:e96502.

7. Yu W, Wang H, Ying H, Yu Y, Chen D, Ge W, et al. Daphnetin attenuates microglial activation and proinflammatory factor production via multiple signaling pathways. Int Immunopharmacol. 2014;21:1-9.

8. Liu Z, Liu J, Zhao K, Shi Q, Zuo T, Wang G, et al. Role of daphnetin in rat severe acute pancreatitis through the regulation of TLR4/ NFKB signaling pathway activation. Am J Chin Med. 2016;44:149-63.

9. Wang D, Lu Z, Zhang H, Jin SF, Yang H, Li YM, et al. Daphnetin alleviates experimental autoimmune encephalomyelitis via regulating dendritic cell activity. CNS Neurosci Ther. 2016;22:558-67.

10. Thuong PT, Hung TM, Ngoc TM, Ha DT, Min BS, Kwack SJ, et al. Antioxidant activities of coumarins from Korean medicinal plants and their structure-activity relationships. Phytother Res. 2010;24:101-6.

11. Duggirala S, Nankar RP, Rajendran S, Doble M. Phytochemicals as inhibitors of bacterial cell division protein FtsZ: coumarins are promising candidates. Appl Biochem Biotechnol. 2014;174:283-96.

12. Huang F, Tang LH, Yu LQ, Ni YC, Wang QM, Nan FJ. In vitro potentiation of antimalarial activities by daphnetin derivatives against Plasmodium falciparum. Biomed Environ Sci. 2006;19:367-70.

13. Kumar A, Sunita $P$, Jha S, Pattanayak SP. Daphnetin inhibits TNF- $\alpha$ and VEGF-induced angiogenesis through inhibition of the IKKs/I $\mathrm{K} \alpha / \mathrm{NF}-\kappa \mathrm{B}$, Src/FAK/ERK1/2 and Akt signaling Pathways. Clin Exp Pharmacol Physiol. 2016;43:939-50.

14. Yang EB, Zhao YN, Zhang K, Mack P. Daphnetin, one of coumarin derivatives, is a protein kinase inhibitor. Biochem Biophys Res Commun. 1999;260:682-5.

15. Finn GJ, Kenealy E, Creaven BS, Egan DA. In vitro cytotoxic potential and mechanism of action of selected coumarins, using human renal cell lines. Cancer Lett. 2002;183:61-8.

16. Jiménez-Orozco FA, Rosales AA, Vega-López A, Domínguez-López ML, García-Mondragón MJ, Maldonado-Espinoza A, et al. Differential effects of esculetin and daphnetin on in vitro cell proliferation and in vivo estrogenicity. Eur J Pharmacol. 2011;668:35-41.

17. Wang Y, Li CF, Pan LM, Gao ZL. 7,8-Dihydroxycoumarin inhibits A549 human lung adenocarcinoma cell proliferation by inducing apoptosis via suppression of Akt/NF-kB signaling. Exp Ther Med. 2013;5:1770-4.

18. Finn GJ, Creaven BS, Egan DA. Daphnetin induced differentiation of human renal carcinoma cells and its mediation by p38 mitogen-activated protein kinase. Biochem Pharmacol. 2004;67:1779-88.

19. Kimura Y, Sumiyoshi M. Antitumor and antimetastatic actions of dihydroxycoumarins (esculetin or fraxetin) through the inhibition of M2 macrophage differentiation in tumor-associated macrophages and/or G1 arrest in tumor cells. Eur J Pharmacol. 2015;746:115-25.

20. Tejeda M, Gaal D, Hullan L, Csuka O, Schwab R, Szokoloczi O, et al. Continuous Administration of the somatostatin structural derivative /TT232 / by subcutaneously implanted osmotic pump improves the efficacy and potency of antitumor therapy in different mouse and human tumor models. Anticancer Res. 2008;28:2769-74.

21. Kawaii S, Tomono Y, Ogawa K, Sugiura M, Yano M, Yoshizawa, et al. The antiproliferative effect of coumarins on several cancer cell lines. Anticancer Res. 2001;21:917-24.

22. Kawase M, Sakagami H, Hashimoto K, Tani S, Hauer H, Chatterjee SS. Structure-cytotoxic activity relationships of simple hydroxylated coumarins. Anticancer Res. 2003;23:3243-46.

23. Reagan-Shaw $S$, Nihal M, Ahmad N. Dose translation from animal to human studies revisited. FASEB J. 2008;3:659-61. 